\title{
OzASOPISMO TECHNIOZNE
}

2. $5-\mathrm{M} / 2008$

ISSN 0011-4561

ISSN 1897-6328

WYDAWNICTWO POLITECHNIKI KRAKOWSKIEJ

JIŘÍ BROŽ, FRANTIŠEK RIEGER*

\section{MIXING OF SUSPENSIONS IN TALL VESSELS WITH A DRAUGHT TUBE}

\author{
WYTWARZANIE ZAWIESINY \\ W SMUKŁYCH MIESZALNIKACH \\ Z RURĄ CYRKULACYJNA
}

\begin{abstract}
The paper deals with particle suspension measurements in tall vessel with axial flow agitator in a draught tube. The effect of particle size and content on agitator speed required for particle suspending is reported. Keywords: tall vessel, draught tube, suspension, pitched blade turbine

Streszczenie

$\mathrm{W}$ pracy przedstawiono wyniki badań nad wytwarzaniem suspensji $\mathrm{w}$ smukłych mieszalnikach $\mathrm{z}$ mieszadłem osiowym w rurze cyrkulacyjnej. Przedstawiono wpływ wielkości cząstek oraz udziału ciała stałego na częstość obrotów niezbędną do wytwarzania zawiesiny.

Stowa kluczowe: mieszalnik smukly, rura cyrkulacyjna, zawiesina, mieszadlo z topatkami pochylonymi
\end{abstract}

\footnotetext{
* Ing. Jiří Brož; Prof. Ing. František Rieger, DrSc.,

Ústav procesní a zpracovatelské techniky, České vysoké učení technické v Praze.
} 


\section{Introduction}

Large tall vessels with a draught tube are used for the mixing of suspensions especially where high homogeneity or heat transfer are desirable. Tall vessels are also advantageous for high pressure. For many years the traditional approach to this situation was to use air lift agitation, commonly known as Pacucha systems [1]. Pacucha systems require high energy input and for this reason air lift was substituted by the axial flow impeller in the upper part of the draught tube. Advantage of this arrangement over standard mixing equipment was established by comparison of the agitator power consumption needed for suspension of solid particles $[2,3]$. The aim of this paper was to determine the effect of particle size and content on agitator speed required for particle suspending.

\section{Theoretical background}

The measurements of particle suspending were evaluated according to recommendation derived in [4] as a dimensionless dependence of modified Froude number

$$
\mathrm{Fr}^{\prime}=\frac{n^{2} \cdot d \rho}{g \cdot \Delta \rho}
$$

on the dimensionless particle size $d_{p} / D$ and particle volumetric concentration $c_{v}$

$$
\mathrm{Fr}^{\prime}=f\left(\frac{d_{p}}{D}, c_{v}\right)
$$

For relatively small particles, the dependence between modified Froude number and dimensionless particle size can be proposed in power form

$$
\mathrm{Fr}^{\prime}=A \cdot\left(\frac{d_{p}}{D}\right)^{a}
$$

The values of coefficients $A$ and $a$ depend on particle volumetric concentration. The mathematical description of these dependencies was proposed by Rieger [5] in the form

$$
\begin{gathered}
A=A_{1} \cdot \exp \left(A_{2} \cdot c_{v}\right) \\
a=a_{1}+a_{2} \cdot c_{v}
\end{gathered}
$$

\section{Experimental}

The experiments were carried out in model mixing equipment with Perspex vessel shown in Fig. 1 with the dimensions presented in Table 1. The water suspensions of five fractions of glass balotine with mean volumetric diameters in the range from 0,15 to $1,28 \mathrm{~mm}$ were used in measurements up to mean volumetric content of $40 \%$. The suspension speed $n_{k}$ was determined visually by decreasing the agitator speed to the state at 
which the solid particles began to settle. The speed of agitator required to initiate suspension $n_{p}$ was also determined by increasing the agitator speed to the value at which all particles were suspended. The speed of the agitator was measured photoelectrically.

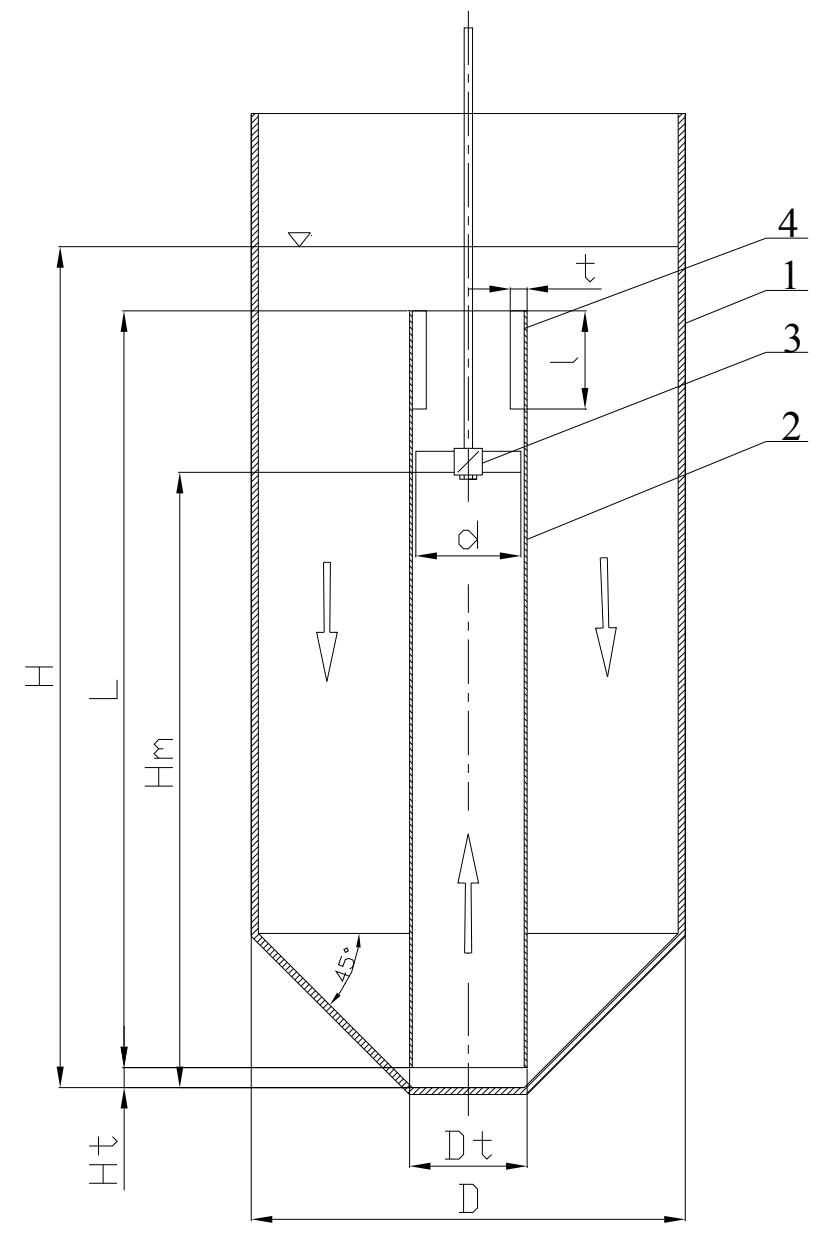

1 . vessel

2. draught tube

3. impeller

4. baffles

4
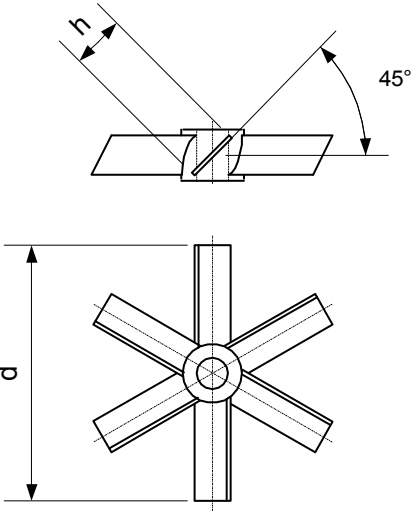

Pitched six-blade turbine

CVS $691020 \mathrm{~h} / \mathrm{d}=0,2$

Fig. 1. Vessel with a draught tube

Rys. 1. Mieszalnik z rurą cyrkulacyjną 
Dimensions of experimental mixing equipment

\begin{tabular}{|c|c|c|c|c|c|c|c|c|}
\hline $\begin{array}{c}D \\
{[\mathrm{~mm}]}\end{array}$ & $\begin{array}{c}D_{t} \\
{[\mathrm{~mm}]}\end{array}$ & $\begin{array}{c}d \\
{[\mathrm{~mm}]}\end{array}$ & $\begin{array}{c}H \\
{[\mathrm{~mm}]}\end{array}$ & $\begin{array}{c}H_{m} \\
{[\mathrm{~mm}]}\end{array}$ & $\begin{array}{c}H_{t} \\
{[\mathrm{~mm}]}\end{array}$ & $\begin{array}{c}t \\
{[\mathrm{~mm}]}\end{array}$ & $\begin{array}{c}L \\
{[\mathrm{~mm}]}\end{array}$ & $\begin{array}{c}l \\
{[\mathrm{~mm}]}\end{array}$ \\
\hline 300 & 80 & 65 & 600 & 444 & 14 & 8 & 540 & 54 \\
\hline
\end{tabular}

\section{Results}

The results of suspension speed measurements are depicted in Fig. 2.

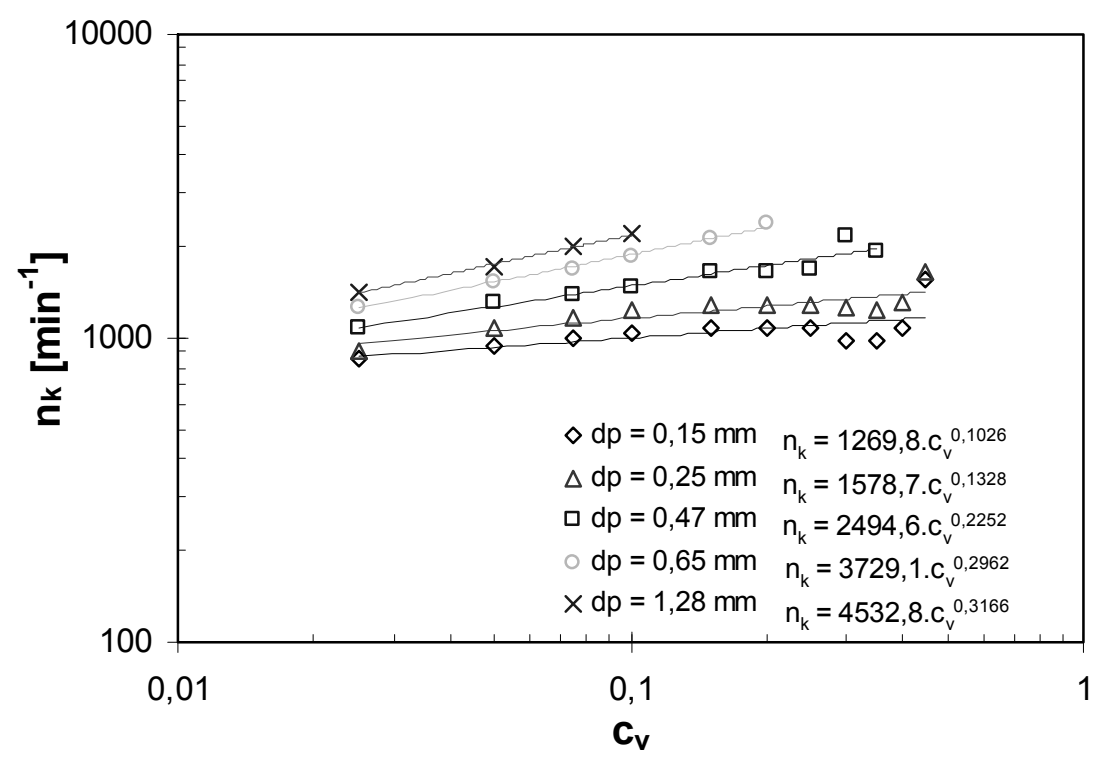

Fig. 2. Dependence of critical speed $n_{k}$ on volumetric particle content $c_{v}$ and particle diameter $d_{p}$

Rys. 2. Zależność prędkości krytycznej $n_{k}$ od zawartości objętościowej cząstek $c_{v}$ i ich średnicy $d_{p}$

The results of agitator speed required to initiate suspension $n_{p}$ are shown in Fig. 3. From both figures it can be seen that suspension speed increases with increasing particle size and content.

From the comparison of both speeds presented in Fig. 4 it can be seen that for small particles the speed to initiate suspension are significantly greater than speed necessary to keep particle in suspension. It is caused by more compact sediment of small particles.

For generalization, the experimental results were recalculated to the dimensionless form of the modified Froude number dependence on the relative particle size according to Eq. (2). This dependence for a few selected concentrations is shown in Fig. 5. From this figure it can be seen that the results can be expressed in the power form of Eq. (3). 


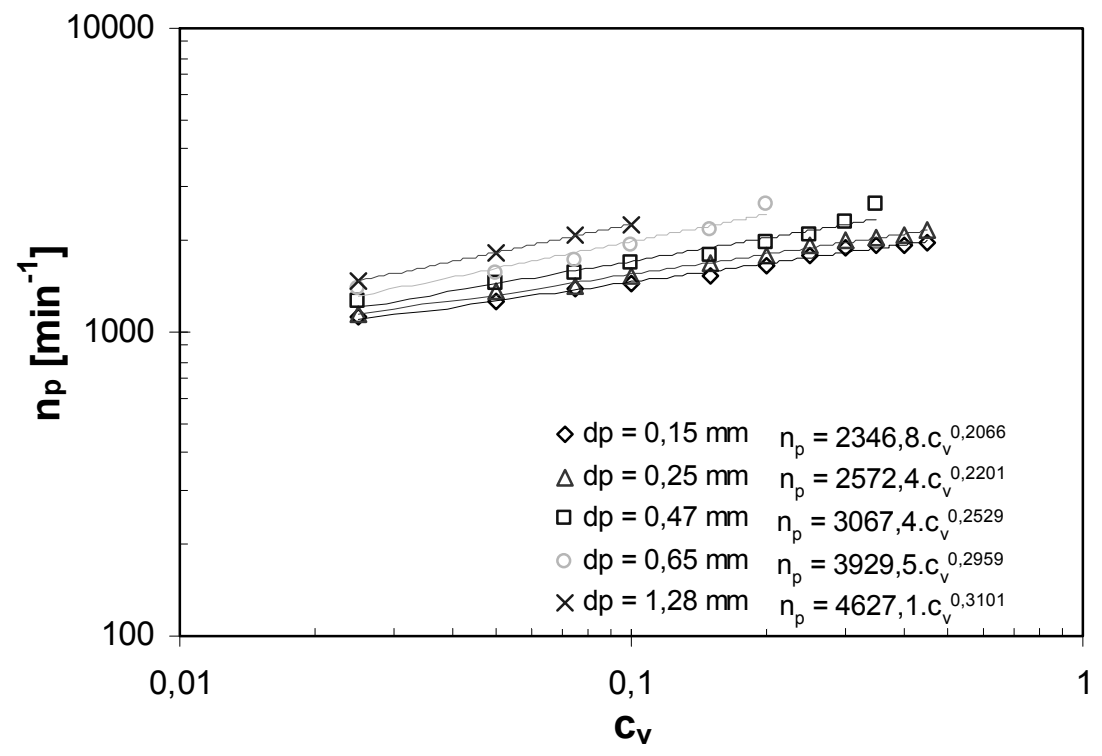

Fig. 3. Dependence of critical speed $n_{p}$ on volumetric particle content $c_{v}$ a and particle diameter $d_{p}$ Rys. 3. Zależność prędkości krytycznej $n_{k}$ od zawartości objętościowej cząstek $c_{v}$ i ich średnicy $d_{p}$

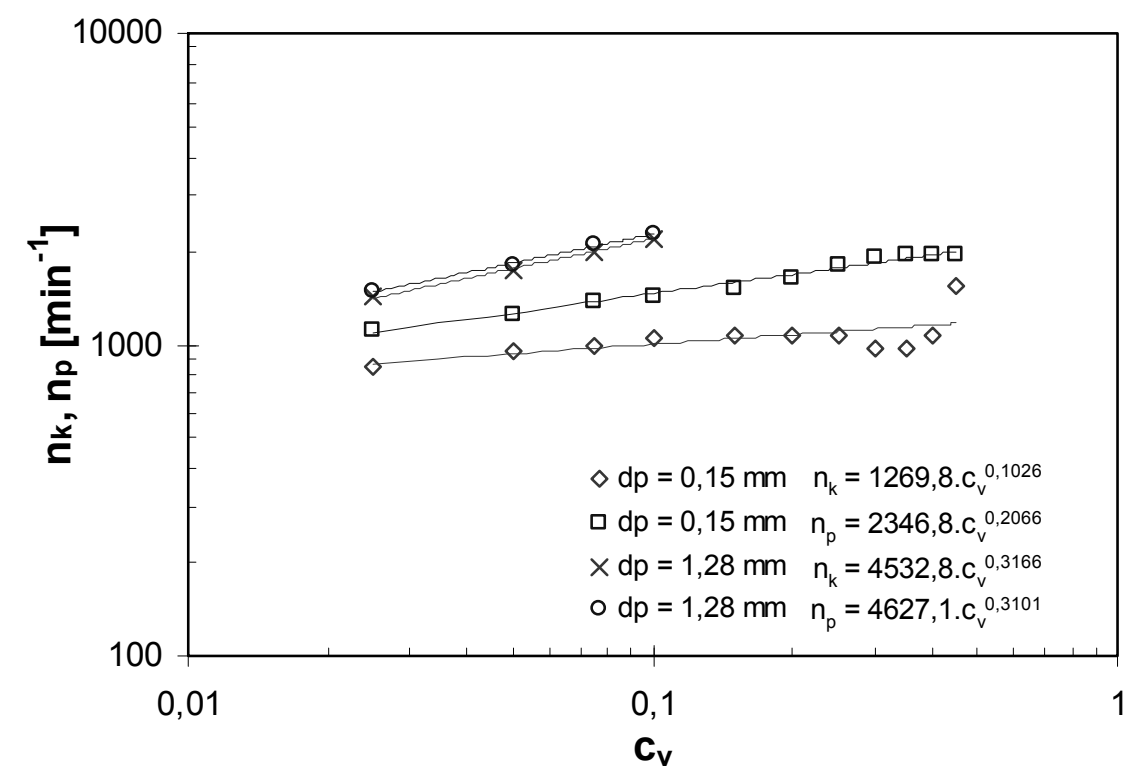

Fig. 4. Comparison of impeller speed $n_{k, p}$ for particle diameters $d_{p}=1,28 ; 0,15 \mathrm{~mm}$

Rys. 4. Porównanie częstości obrotowej mieszadła $n_{k, p}$ dla średnic cząstek $d_{p}=1,28 ; 0,15 \mathrm{~mm}$ 
34

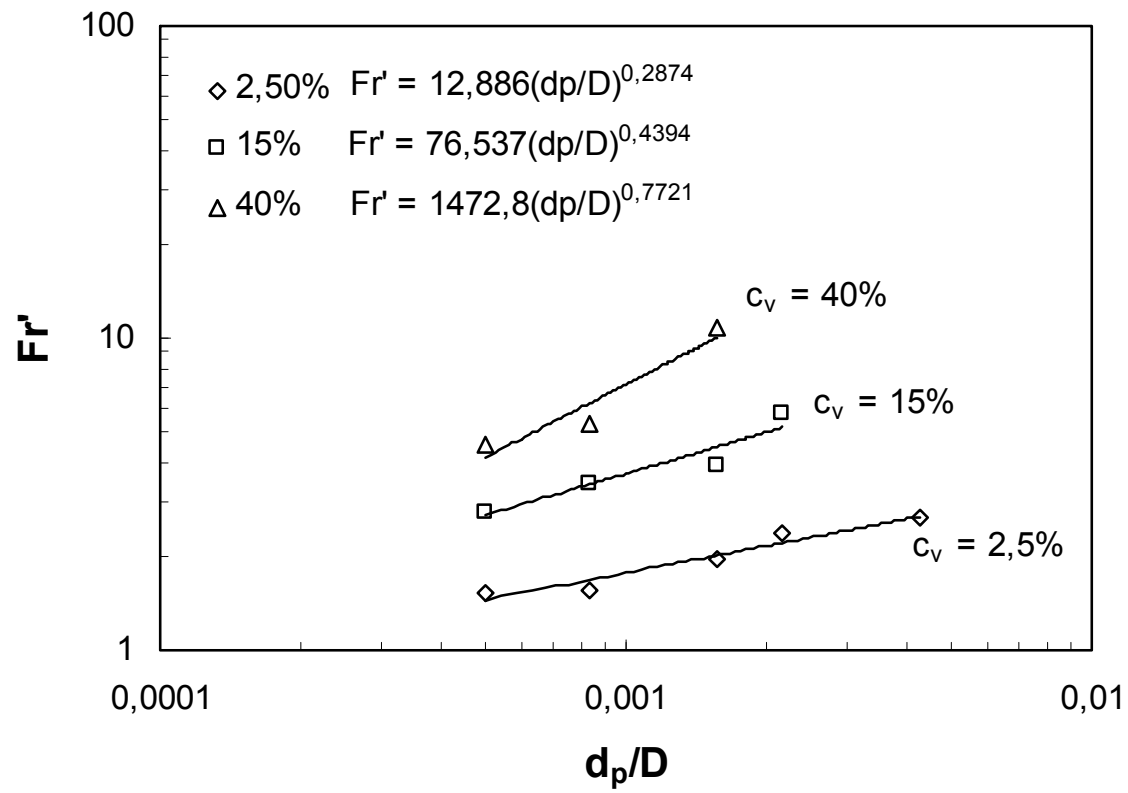

Fig. 5. Dependences of $\mathrm{Fr}^{\prime}$ on the relative particle size $d_{p} / D$ for selected volumentric particle contents $c_{v}=2,5 ; 15$ and $40 \%$

Rys. 5. Zależność Fr' od względnej średnicy cząstek $d_{p} / D$ dla wybranych zawartości objętościowych $c_{v}=2,5 ; 15$ i $40 \%$

The dependences of the coefficients of Equation (3) on concentration for both critical and initial agitator speeds were expressed in form of Eqs. (4) and (5) as it is shown in Fig. 6. 
a) Dependences of coefficients $a_{k p}$ on volumetric concentration $c_{v}$

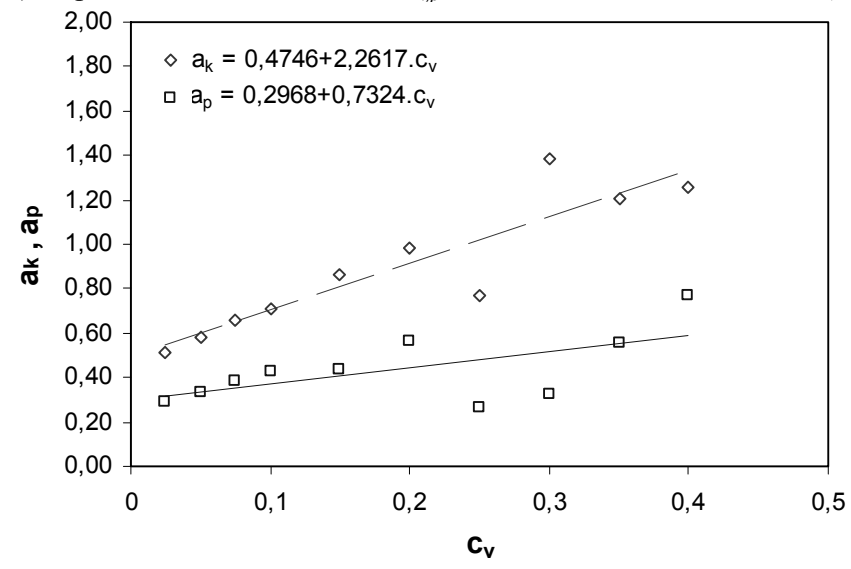

b) Dependences of coefficients $A_{k, p}$ on volumetric concentration $c_{v}$

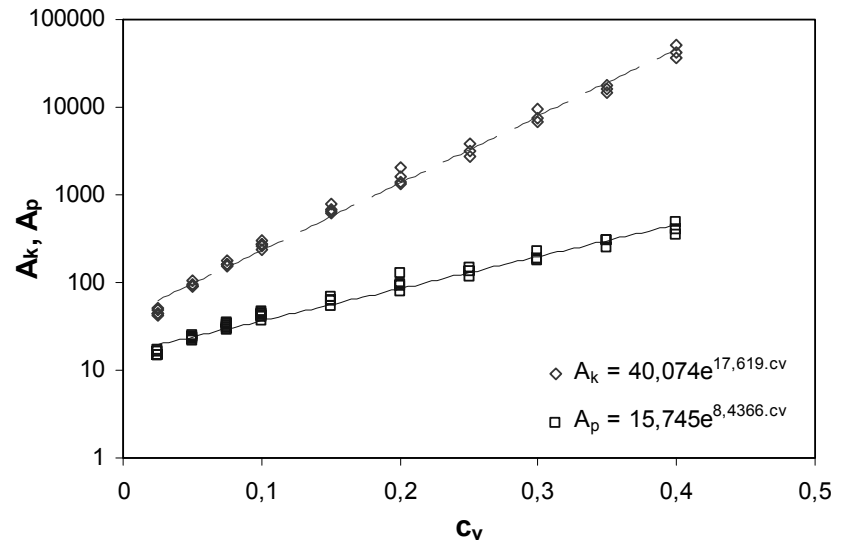

Fig. 6. Dependences of coefficients a) $a_{k, p}$ and b) $A_{k, p}$ on volumetric concentration $c_{v}$

Rys. 6. Zależność współczynników a) $a_{k, p}$ i b) $A_{k, p}$ od zawartości objętościowej $c_{v}$

\section{Conclusions}

From the results presented above it follows that the agitator speed required to initiate particle suspending can be calculated from Eq. (3) with coefficients described by the following equations

$$
\begin{gathered}
A_{p}=15,74 \cdot \exp \left(8,44 c_{v}\right) \\
a_{p}=0,3+0,73 \cdot c_{v}
\end{gathered}
$$


The critical agitator speed necessary to maintain particles in suspension can be also calculated from Eq. (3) with coefficients described by the following equations

$$
\begin{gathered}
A_{k}=40,07 \cdot \exp \left(17,62 \cdot c_{v}\right) \\
a_{k}=0,47+2,26 \cdot c_{v}
\end{gathered}
$$

The agitator of industrial mixing equipment must be able not only to maintain particles in suspension but it must be also able to suspend particles after interruption of mixing.

\section{Symbols}

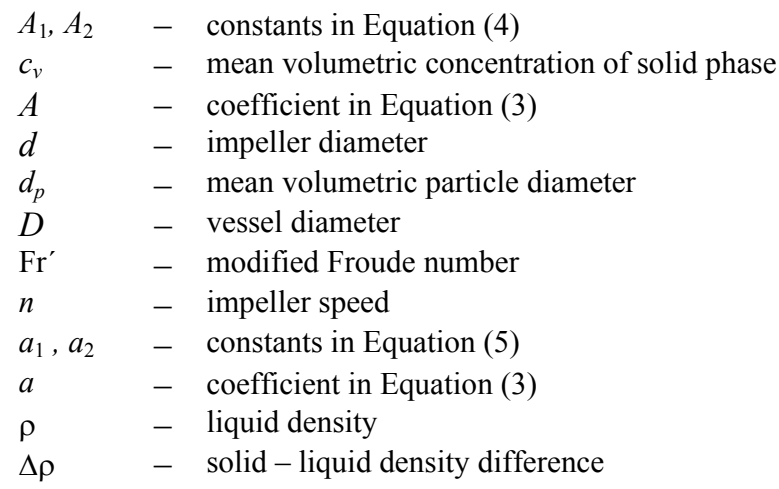

\section{References}

[1] Sh aw J. A .: Proc. Australas. Inst.Min. Metall, 383, 1982, 47-58.

[2] Jiříč k ová E., Ri e ger F .: Chem. Eng. J., 59, 1995, 273-275.

[3] Rieger F .: Proceedings of 24th Conference of Slovak Society of Chemical Engineering, Bratislava 1997, 285-288.

[4] Rieger F., Ditl P .: Chem. Eng. Sci., 49, 1994, 2219-2227.

[5] Ri e g e r F .: Chem. Eng. Proc., 41, 2002, 381-384.

This work was subsided by the research project of Ministry of Education of the Czech Republic MSM6840770035. 